\title{
OXIDATIVE AND MICROBIOLOGICAL STABILITY OF FRESH PORK SAUSAGE WITH ADDED SUN MUSHROOM POWDER
}

\author{
Estabilidade oxidativa e microbiológica de linguiça frescal de carne suína \\ adicionada de pó de cogumelo do sol
}

\author{
Flávia Santi Stefanello ${ }^{1}$, Carlos Pasqualin Cavalheiro ${ }^{2}$, Fernanda Luísa Ludtke², \\ Mariana dos Santos da Silva ${ }^{3}$, Leadir Lucy Martins Fries ${ }^{2}$, Ernesto Hashime Kubota ${ }^{2}$
}

\begin{abstract}
Consumers are becoming more aware of the toxicological implications of artificial additives in foods. Natural antioxidants, in addition to reducing the deleterious effects of lipid oxidation, are currently extremely highly valued. This study aimed to invetigate the effect of addition of sun mushroom (Agaricus blazei Murrill) powder on the oxidative and microbiological stability of pork sausage during the shelf life. This powder was used at concentrations of $0.0 \%, 1.0 \%, 2.0 \%$ and $4.0 \%$ in the sausages. Analyses of moisture, protein, ash, fat and microbiological analyses were performed on day 0 . The sausages were analyzed on day 0 and every seven days in terms of $\mathrm{pH}$, color, TBARS values and microbiological analyses. The results of the proximal composition and microbiological analysis for coagulase positive Staphylococcus, coliforms at $35^{\circ} \mathrm{C}$ and $45^{\circ} \mathrm{C}$, Salmonella sp and sulfite-reducing Clostridium were consistent with those required by Brazilian legislation. The color of the products was of a decreased redness At the end of the storage period, on the 35th day, the TBARS values for the sausage with $4.0 \%$ powder was $0.509 \pm 0.12 \mathrm{mg}$ MDA/ $\mathrm{kg}$ sample and for the control was $1.131 \pm 0.12 \mathrm{mg} \mathrm{MDA} / \mathrm{kg}$ sample. The sun mushroom powder had no effect on microbiological stability. It is concluded that sun mushroom was effective in terms of the oxidative stability of pork sausage when added in powdered form at concentrations of $1.0 \%, 2.0 \%$ and $4.0 \%$.
\end{abstract}

Index terms: Natural antioxidant; microbial count; lipid oxidation; meat product.

\section{RESUMO}

Os consumidores estão se tornando mais conscientes das implicações toxicológicas de aditivos artificiais em alimentos. Nesse sentido, a utilização de compostos antioxidantes naturais, além de reduzir efeitos deletérios da oxidação lipídica, são atualmente mais valorizados no mercado. Dessa forma, objetivou-se determinar o efeito da adição de cogumelo do sol (Agaricus blazei Murril) em pó sobre a estabilidade oxidativa e microbiológica de linguiça frescal de carne suína, ao longo da vida útil. Esse pó foi utilizado nas concentrações de $0 \%, 1,0 \%, 2,0 \%$ e 4,0\%, na fabricação de linguiça. Foram realizadas análises de umidade, proteínas, cinzas, gordura e análises microbiológicas no dia 0 . Analisaram-se as linguiças no dia 0 e a cada sete dias em relação ao pH, cor, índice de TBARS e análises microbiológicas. Os resultados obtidos na composição centesimal e nas análises microbiológicas para Estafilococos coagulase positiva, Coliformes a $35^{\circ} \mathrm{C}$ e a $45^{\circ} \mathrm{C}$, Samonella sp e Clostrídios sulfito redutores estavam de acordo com o exigido pela legislação brasileira. Em relação à cor do produto, ocorreu diminuição na tonalidade vermelha. No período final de estocagem, ao $35^{\circ}$ dia, o valor de TBARS para linguiça com $4,0 \%$ de pó foi de $0,509 \pm 0,12 \mathrm{mg} \mathrm{MDA} / \mathrm{kg}$ de amostra e para o controle foi de $1,131 \pm 0,12 \mathrm{mg} \mathrm{MDA} / \mathrm{kg}$ de amostra. O cogumelo do sol, em pó, não possui efeito sobre a estabilidade microbiológica. Conclui-se que o cogumelo do sol mostrou-se efetivo sobre a estabilidade oxidativa de linguiça de carne suína quando adicionado em pó nas concentrações de $1,0 \%, 2,0 \%$ e $4,0 \%$.

Termos para indexação: Antioxidante natural; contagem microbiana; oxidação lipídica; produto cárneo.

\section{INTRODUCTION}

Fresh sausage is the main industrialized meat product derived from pork that is consumed in Brazil, although its identity standard in Brazil is still underdeveloped (Oliveira; Araújo; Borgo, 2005). This type of fresh sausage should have no more than $70 \%$ moisture, a maximum of $30 \%$ fat and at least $12 \%$ protein (Brasil, 2000).

From a nutritional standpoint, sausage is an important source of protein, with a high biological value. However, sausages also have some technical limitations as a result of their lipid content, which is of animal origin (Gök; Akkaya; Obuz, 2008).

\footnotetext{
${ }^{1}$ Universidade Federal de Santa Maria/UFSM - Centro de Clências Rurais/CCR - Departamento de Tecnologia e Ciência dos Alimentos/DTCA Prédio 42 - Av. Roraima, 1000 - Cidade Universitária - Santa Maria - RS - Brasil - flaviass_vet@hotmail.com

2Universidade Federal de Santa Maria/UFSM - Centro de Clências Rurais/CCR - Departamento de Tecnologia e Ciência dos Alimentos/DTCA - Santa Maria - RS - Brasil

3Universidade Federal de Santa Maria/UFSM - Centro de Ciências da Saúde/CCS - Santa Maria - RS - Brasil

Received in november 17, 2014 and approved in april 17, 2015
}

Ciênc. Agrotec., Lavras, v. 39, n. 4, p. 381-389, jul./ago., 2015 
Lipid oxidation can cause damage to the sensory properties of food because lipids contribute to the perception of taste, texture and juiciness of products (Saggiorato et al., 2012). Lipid decomposition is capable of producing offensive odors and flavors (Georgantelis et al., 2007), as well as the destruction of essential constituents and the formation of toxic compounds during processing that may present a risk to consumer health (Dejong; Lanari, 2009).

Consequently, various artificial additives have been added to products to prevent unwanted reactions connected with lipid oxidation, designed to increase the shelf life of meat products. However, consumers are becoming more aware of the toxicological implications of artificial additives (Georgantelis et al., 2007). In high doses, some of these compounds may exert carcinogenic and/or mutagenic effects (Fellenberg; Speisky, 2006).

Natural antioxidants, in addition to reducing the deleterious effects of lipid oxidation, are currently extremely highly valued. The potential antioxidant effect of various natural compounds, including ascorbic acid, tocopherols, carotenoids and other phenolic compounds has been reported, which have all been evaluated in food matrices, including meat products (Capitani et al., 2009).

Brazil is the world's largest producer of sun mushrooms (Agaricus blazei Murrill), which is a native species, with favorable climatic conditions in Brazil for its cultivation (Tomizawa, et al., 2007). Some edible mushrooms, including sun mushroom, have important therapeutic properties and have been traditionally used in oriental medicine (Taveira; Novaes, 2007).

It has been scientifically proven that sun mushroom (Agaricus blazei Murrill) may represent a viable and economical source of antioxidants in the diet because they have a very effective in vitro antioxidant effect (Soares et al., 2009). In this context, and taking into account the growing demand for foods with added natural compounds, the antioxidant and antimicrobial evaluation of sun mushroom powder in pork sausage is an important area of research.

Thus, the objective of this study was to determine the effect of the addition of sun mushroom (Agaricus blazei Murrill) powder on the oxidative and microbiological stability of fresh pork sausage during the shelf life of the product.

\section{MATERIAL AND METHODS}

The samples of sun mushroom used in this study were provided by a commercial firm located in the city of Santa Maria (RS-Brazil) in the form of pre-dried immature fruiting bodies. The samples were ground in a refrigerated analytical mill $\left(4^{\circ} \mathrm{C}\right)$ (Quimis, model Q 298A21, Diadema, Brazil) and placed in closed containers, protected from light and in a freezer $\left(-12^{\circ} \mathrm{C}\right)$ until ready to be used.

The raw materials and ingredients that were used were purchased from outlets located in Santa Maria (RSBrazil). The preparation of the pork sausages took into account the requirements set out by legislation (Brasil, 2000) and procedures described by Terra and Brum (1998). Initially, the pork and pork fat were ground in a grinder (Jamar PJ22, Jamar Ltda, São Paulo, Brazil). In the next step, the meat mixture was placed in the mixing machine (JEM Jamar 35) and the other ingredients were added and mixed to obtain a bind.

The meat mixture was then divided into four lots of $5 \mathrm{~kg}$, into which were added the pre-defined concentrations of sun mushroom powder (SP), which yielded four treatments: treatment $1(0.0 \% \mathrm{SP})$ - sausage without added SP; treatment $2(1.0 \% \mathrm{SP})$ - sausage with $1.0 \%$ added SP; treatment $3(2.0 \% \mathrm{SP})$ - sausage with $2.0 \%$ added SP; treatment $4(4.0 \% \mathrm{SP})$ - sausage with $4.0 \%$ added SP.

After, the meat mixtures were packed into pig casing. For storage, the sausages were packed in polystyrene trays, wrapped with plastic wrap, identified and immediately taken to a BOD oven (ELETROLAB, model EL 101, São Paulo, Brazil) and stored at $4{ }^{\circ} \mathrm{C}$.

Moisture analysis was performed in an oven at $105^{\circ} \mathrm{C}$, ash analysis was performed in an oven at $550{ }^{\circ} \mathrm{C}$, and protein was assessed by the Kjeldahl method according to the methodology described by the Association of Official Analytical Chemists (Association Of Official Analytical Chemists-AOAC, 2005). The analysis of fat was performed according to the (Instituto Adolfo LutzIAL, 2008), using the butyrometer method.

The measurement of $\mathrm{pH}$ was performed on days $0,7,14,21,28$ and 35 of manufacture. The $\mathrm{pH}$ was determined in the homogenate (DIGIMED, model DM23DC-pH meter, São Paulo, Brazil), with readings in triplicate (Terra; Brum, 1988).

Color determination was evaluated by the CIELAB system, using a CR-300 chroma meter (MINOLTA, Osaka, Japan) on days $0,7,14,21,28$ and 35 of storage. The results were expressed as $L^{*}$ (representing the percentage of brightness), $a^{*}$ (where: it $-a^{*}$ represents direction towards green and $+a^{*}$ toward represents direction towards red), $b^{*}$ (where: $-b^{*}$ represents direction towards blue and $+b^{*}$ represents direction towards yellow), $C^{*}$ (saturation index) and $h^{*}$ (hue angle). The sausage casing was removed and the mass was homogenized and then distributed in Petri dish. The reading was performed at 
random on surface of the plate. The mean value of five readings for each treatment was obtained. Each reading the mass of sausage was mixed and homogenized again.

The assessment of lipid oxidation of the pork sausages was conducted by the thiobarbituric acid reactive substances (TBARS) test, according to Raharjo, Sofos and Scmidt (1992). The TBARS values were determined in quintuplicate for each sample on days $0,7,14,21,28$ and 35 , and the results were expressed as mg malonaldehyde per kg of sample.

The microbiological analysis was performed on days $0,7,14,21,28$ and 35 of storage at $4{ }^{\circ} \mathrm{C}$ for mesophilic and psychrotrophic microorganisms, while the microbiological analyses of coliforms at $35^{\circ} \mathrm{C}$, coliforms at $45^{\circ} \mathrm{C}$, Staphylococcus coagulase positive, Salmonella $s p$, and sulphite-reducing Clostridium were performed only on day 0 of storage. All of these analyses were conducted in quadruplicate (American Public Health AssociationAPHA, 2001; Brasil, 2003).

The results were statistically analyzed by one-way analysis of variance (ANOVA) and comparison of means test (Tukey), using a significance level of 5\%. The analyses were performed using SPSS 17.0 statistical software.

\section{RESULTS AND DISCUSSION}

The results for the proximal composition of the pork sausages with added sun mushroom (Agaricus blazei Murrill) powder showed that the products conformed to the identity and quality of product standard (Brasil, 2000) (Table 1). It can be seen that there were differences $(p<0.05)$ in the percentages of moisture and protein between the treatments. In contrast, the values of ash and fat did not differ ( $\mathrm{p}>0.05)$.

It can also be seen that the addition of sun mushroom powder influenced the moisture values between the treatments, so that the pork sausage without added powder $(0 \% \mathrm{SP})$ showed higher moisture values $(\mathrm{p}<0.05)$ in relation to the other formulations, demonstrating that the addition of sun mushroom powder in the different tested concentrations was able to reduce moisture values.

In relation to protein content, the addition of sun mushroom powder increased protein values in proportion to the level of added powder in the treatments. The high percentage of protein in this type of mushroom has been reported by Agahar-Murukar and Subbulakshmi (2005).

The results of the effect of the addition of sun mushroom (Agaricus blazei Murril) powder on the $\mathrm{pH}$ of the pork sausages during storage at $4{ }^{\circ} \mathrm{C}$ (Table 2) showed that globally the $\mathrm{pH}$ decreased $(\mathrm{p}<0.05)$ during storage. At the start of the testing the $\mathrm{pH}$ showed no statistical difference $(p>0.05)$ between the control and the other treatments. However, from day 21, the $\mathrm{pH}$ was lower $(\mathrm{p}<0.05)$ in the control sample. This can be partially attributed to the high $\mathrm{pH}$ of the sun mushroom powder (6.62 \pm 0.04$)$.

The decrease in $\mathrm{pH}$ over the storage days was also reported by Joseph et al. (2012) in chilled meat product added tomato compounds, and in treatments with added pure tomato $10 \%$ and lyophilized tomato $6 \%$ was observed, respectively, a significant reduction attributed to $\mathrm{pH}$ inherent differences $\mathrm{pH}$ tomato products added.

The TBARS test quantifies malondialdehyde, which one of the major products of the decomposition of the hydroperoxides of polyunsaturated fatty acids formed during the oxidation process. The TBARS values increased $(p<0.05)$ during storage for all the treatments, demonstrating the development of lipid oxidation (Table 3).

However, there were significant differences $(\mathrm{p}<0.05)$ between the control and the other treatments and it was noted that that over the period of storage, the treatment with $4 \%$ added sun mushroom powder had a lower TBARS value $(\mathrm{p}<0.05)$ than the control and treatments $1 \%(\mathrm{SP})$ and $2 \%(\mathrm{SP})$.

Table 1: Proximal composition of fresh pork sausages with different added concentrations of sun mushroom powder (Agaricus blazei Murrill) stored at $4{ }^{\circ} \mathrm{C}$ for 35 days.

\begin{tabular}{crcrr}
\hline & $0 \% \mathrm{SP}$ & $1.0 \% \mathrm{SP}$ & $2.0 \% \mathrm{SP}$ & \multicolumn{1}{c}{$4.0 \% \mathrm{SP}$} \\
\hline Moisture $\mathrm{g}(\%)$ & $61.21 \pm 0.71 \mathrm{a}$ & $58.75 \pm 0.85 \mathrm{ab}$ & $58.60 \pm 0.43 \mathrm{ab}$ & $57.77 \pm 0.94 \mathrm{~b}$ \\
Protein $\mathrm{g}(\%)$ & $18.07 \pm 1.30 \mathrm{~b}$ & $18.98 \pm 0.80 \mathrm{ab}$ & $21.18 \pm 1.60 \mathrm{a}$ & $20.69 \pm 1.52 \mathrm{a}$ \\
Ash $\mathrm{g}(\%)$ & $3.70 \pm 0.18 \mathrm{a}$ & $3.49 \pm 0.25 \mathrm{a}$ & $3.73 \pm 0.17 \mathrm{a}$ & $3.86 \pm 0.27 \mathrm{a}$ \\
Fat $\mathrm{g}(\%)$ & $12.71 \pm 1.32 \mathrm{a}$ & $12.34 \pm 1.33 \mathrm{a}$ & $12.67 \pm 0.67 \mathrm{a}$ & $13.88 \pm 0.90 \mathrm{a}$ \\
\hline
\end{tabular}

${ }^{a}$ Averages in the same row with the same superscript letters do not differ significantly by Tukey's test $(\mathrm{p}<0.05)$. Means \pm standard deviation of triplicate analyses. $\mathrm{SP}=$ sun mushroom powder. 
Table 2: $\mathrm{pH}$ values of fresh pork sausage with different added concentrations of sun mushroom powder (Agaricus blazei Murrill) stored at $4{ }^{\circ} \mathrm{C}$ for 35 days.

\begin{tabular}{cllll}
\hline & \multicolumn{1}{c}{$0 \% \mathrm{SP}$} & \multicolumn{1}{c}{$1.0 \% \mathrm{SP}$} & \multicolumn{1}{c}{$2.0 \% \mathrm{SP}$} & \multicolumn{1}{c}{$4.0 \% \mathrm{SP}$} \\
\hline Day 0 & $5.86 \pm 0.127 \mathrm{bA}$ & $5.89 \pm 0.04 \mathrm{abA}$ & $6.03 \pm 0.04 \mathrm{abA}$ & $6.05 \pm 0.02 \mathrm{aA}$ \\
Day 7 & $5.97 \pm 0.066 \mathrm{aA}$ & $5.91 \pm 0.04 \mathrm{aA}$ & $5.86 \pm 0.05 \mathrm{aAB}$ & $5.95 \pm 0.01 \mathrm{aAB}$ \\
Day 14 & $6.04 \pm 0.060 \mathrm{aA}$ & $5.94 \pm 0.05 \mathrm{aA}$ & $5.89 \pm 0.07 \mathrm{aAB}$ & $5.98 \pm 0.01 \mathrm{aBC}$ \\
Day 21 & $5.73 \pm 0.073 \mathrm{bAB}$ & $5.87 \pm 0.05 \mathrm{aA}$ & $5.92 \pm 0.09 \mathrm{aAB}$ & $5.87 \pm 0.02 \mathrm{aCD}$ \\
Day 28 & $5.64 \pm 0.038 \mathrm{bBC}$ & $5.86 \pm 0.04 \mathrm{aA}$ & $5.80 \pm 0.03 \mathrm{aB}$ & $5.79 \pm 0.07 \mathrm{aDE}$ \\
Day 35 & $5.45 \pm 0.035 \mathrm{bC}$ & $5.69 \pm 0.01 \mathrm{abB}$ & $5.56 \pm 0.11 \mathrm{abC}$ & $5.77 \pm 0.01 \mathrm{aE}$ \\
\hline
\end{tabular}

${ }^{a}$ Averages in the same row with the same superscript letters do not differ significantly by Tukey's test ( $\left.p<0.05\right)$. ${ }^{\mathrm{A}}$ Averages in the same column with the same superscript letters do not differ significantly by Tukey's test $(p<0.05)$. Means \pm standard deviation of triplicate analyses. $\mathrm{SP}=$ sun mushroom powder.

Table 3: Average TBARS values (mg MDA/kg sample) of samples of fresh pork sausage with different added concentrations of sun mushroom (Agaricus blazei Murrill) powder stored at $4{ }^{\circ} \mathrm{C}$ for 35 days.

\begin{tabular}{cllll}
\hline & \multicolumn{1}{c}{$0 \% \mathrm{SP}$} & \multicolumn{1}{c}{$1.0 \% \mathrm{SP}$} & \multicolumn{1}{c}{$2.0 \% \mathrm{SP}$} & \multicolumn{1}{c}{$4.0 \% \mathrm{SP}$} \\
\hline Day 0 & $0.485 \pm 0.09 \mathrm{aC}$ & $0.264 \pm 0.09 \mathrm{bD}$ & $0.283 \pm 0.09 \mathrm{bC}$ & $0.125 \pm 0.09 \mathrm{bD}$ \\
Day 7 & $0.537 \pm 0.05 \mathrm{aC}$ & $0.395 \pm 0.04 \mathrm{bCD}$ & $0.412 \pm 0.06 \mathrm{bBC}$ & $0.234 \pm 0.05 \mathrm{cCD}$ \\
Day 14 & $0.628 \pm 0.05 \mathrm{aBC}$ & $0.452 \pm 0.04 \mathrm{bBC}$ & $0.481 \pm 0.05 \mathrm{bB}$ & $0.371 \pm 0.06 \mathrm{cBC}$ \\
Day 21 & $0.878 \pm 0.09 \mathrm{aB}$ & $0.627 \pm 0.09 \mathrm{bA}$ & $0.555 \pm 0.01 \mathrm{bcAB}$ & $0.410 \pm 0.09 \mathrm{cB}$ \\
Day 28 & $0.763 \pm 0.07 \mathrm{aB}$ & $0.515 \pm 0.08 \mathrm{bABC}$ & $0.326 \pm 0.09 \mathrm{cBC}$ & $0.264 \pm 0.06 \mathrm{cC}$ \\
Day 35 & $1.131 \pm 0.12 \mathrm{aA}$ & $0.604 \pm 0.12 \mathrm{bAB}$ & $0.585 \pm 0.11 \mathrm{bA}$ & $0.509 \pm 0.12 \mathrm{bA}$ \\
\hline
\end{tabular}

${ }^{a}$ Averages in the same row with the same superscript letters do not differ significantly by Tukey's test ( $\left.\mathrm{p}<0.05\right)$. ${ }^{\mathrm{A}}$ Averages in the same column with the same superscript letters do not differ significantly by Tukey's test $(\mathrm{p}<0.05)$. Means $\pm \mathrm{SD}$ of quintuplicate analyses. $\mathrm{SP}=$ sun mushroom powder.

Ahmad and Srivastava (2007) reported that in the range of TBARS values between 0.5 and $1.0 \mathrm{mg} \mathrm{MDA} / \mathrm{kg}$ of meat samples, it was not possible to detect rancid odors. However, TBARS values between 1 and $2 \mathrm{mg}$ MDA $/ \mathrm{kg}$ in a sample sensorially denote lipid oxidation. The TBARS values found for the pork sausage in the present study showed that only the treatment without the addition of sun mushroom powder, on the 35th day of storage, showed a value higher than $1 \mathrm{mg} \mathrm{MDA} / \mathrm{kg}$ of sample $(1.131 \pm 0.12$ mg MDA $/ \mathrm{kg}$ of sample).

Kim, Cho and Han (2013) reported TBARS values for a bovine fresh sausage added plant extract of Chamnamul green leaf(a plant typical of East Asia). These results demonstrate that the addition of phenolic compounds from plant sources is able to protect meat products against damage from lipid oxidation, provided that they are at a suitable concentration.

Oxidative processes are associated with the discoloration of these products because lipid oxidation results in the formation of pro-oxidants that are capable of reacting with oxymyoglobin, leading to the formation of metmyoglobin; this change contributes to the development changes in color (Georgantelis et al., 2007).

The $L^{*}$ (lightness) values of the pork sausages varied $(p<0.05)$ between treatments and days of storage (Table 4). From 0 days to the 35 th day of storage the $L^{*}$ value was lower $(p<0.05)$ in the treatments with added sun mushroom powder. The most pronounced difference was between the control and the treatment with $4 \%$ added SP. These results indicate that the pork sausages with different added concentrations of sun mushroom powder become darker than the control, given that $L^{*}$ values range from black $(0 \%)$ to white $(100 \%)$ (Comission Internationale de I'Eclairage-CIE 1986; Ramos; Gomide, 2007).

Joseph et al. (2012) also reported a decrease in the $L^{*}$ value in refrigerated meat products with 
added tomato compounds, when compared to control. Similar observations were also reported in pork sausage stored under refrigeration with the addition of extracts of curry leaves and mint (Biswas, Chatli;
Sahoo, 2012) and it is possible to confirm that plant extracts incorporated into meat products are able to change the color of the product (Kim, Cho and Han, 2013).

Table 4: Instrumental color parameters $\left(L^{*}, a^{*}, b^{*}, C^{*}\right.$ and $\left.h^{*}\right)$ of fresh pork sausage with different added concentrations of sun mushroom (Agaricus blazei Murrill) powder stored at $4{ }^{\circ} \mathrm{C}$ for 35 days.

\begin{tabular}{|c|c|c|c|c|c|}
\hline & & $0 \% \mathrm{SP}$ & $1.0 \% \mathrm{SP}$ & $2.0 \% \mathrm{SP}$ & $4.0 \% \mathrm{SP}$ \\
\hline \multirow{6}{*}{$\mathrm{L}^{*}$} & Day 0 & $53.99 \pm 0.53 \mathrm{aD}$ & $51.15 \pm 1.15 \mathrm{bE}$ & $51.55 \pm 1.49 \mathrm{bB}$ & $47.86 \pm 0.79 \mathrm{cC}$ \\
\hline & Day 7 & $60.90 \pm 0.66 \mathrm{aBC}$ & $57.24 \pm 0.61 \mathrm{bBC}$ & $58.08 \pm 0.98 \mathrm{bA}$ & $54.72 \pm 1.25 \mathrm{cA}$ \\
\hline & Day 14 & $60.73 \pm 1.09 \mathrm{aBC}$ & $56.52 \pm 0.52 b C D$ & $56.71 \pm 0.91 \mathrm{bA}$ & $50.89 \pm 1.40 \mathrm{cB}$ \\
\hline & Day 21 & $64.45 \pm 1.45 \mathrm{aA}$ & $58.56 \pm 1.06 \mathrm{bB}$ & $56.49 \pm 1.44 \mathrm{bA}$ & $47.87 \pm 0.96 \mathrm{cC}$ \\
\hline & Day 28 & $61.43 \pm 1.17 \mathrm{aB}$ & $60.90 \pm 0.75 \mathrm{bA}$ & $57.51 \pm 1.31 \mathrm{bA}$ & $53.16 \pm 1.64 \mathrm{cAB}$ \\
\hline & Day 35 & $58.95 \pm 0.83 \mathrm{aC}$ & $55.15 \pm 0.59 \mathrm{bD}$ & $50.89 \pm 1.35 \mathrm{cB}$ & $44.44 \pm 1.09 \mathrm{dD}$ \\
\hline \multirow{6}{*}{$a^{*}$} & Day 0 & $16.49 \pm 0.34 \mathrm{aA}$ & $15.76 \pm 0.63 \mathrm{abA}$ & $14.89 \pm 0.53 \mathrm{bA}$ & $11.51 \pm 0.38 \mathrm{cA}$ \\
\hline & Day 7 & $13.87 \pm 0.37 \mathrm{aB}$ & $12.38 \pm 0.19 \mathrm{bB}$ & $10.87 \pm 0.37 \mathrm{cB}$ & $10.53 \pm 0.95 \mathrm{cAB}$ \\
\hline & Day 14 & $13.18 \pm 1.26 \mathrm{aBC}$ & $11.76 \pm 0.58 \mathrm{bBC}$ & $10.05 \pm 0.24 \mathrm{bBC}$ & $10.10 \pm 0.65 \mathrm{bB}$ \\
\hline & Day 21 & $12.05 \pm 0.66 \mathrm{aC}$ & $11.07 \pm 0.56 \mathrm{bC}$ & $10.23 \pm 0.76 \mathrm{bBC}$ & $8.04 \pm 0.66 c \mathrm{C}$ \\
\hline & Day 28 & $12.79 \pm 1.11 \mathrm{aC}$ & $10.26 \pm 0.58 \mathrm{bD}$ & $10.37 \pm 0.91 \mathrm{bBC}$ & $8.33 \pm 0.23 c C$ \\
\hline & Day 35 & $11.48 \pm 0.46 \mathrm{aC}$ & $10.05 \pm 0.23 \mathrm{bD}$ & $9.76 \pm 0.49 \mathrm{bC}$ & $8.75 \pm 0.29 c C$ \\
\hline \multirow{6}{*}{$b^{*}$} & Day 0 & $11.38 \pm 0.61 \mathrm{dA}$ & $14.91 \pm 0.11 \mathrm{cC}$ & $17.53 \pm 0.41 \mathrm{bAB}$ & $19.51 \pm 0.57 \mathrm{aB}$ \\
\hline & Day 7 & $11.81 \pm 0.56 \mathrm{dA}$ & $16.57 \pm 0.89 \mathrm{cAB}$ & $18.82 \pm 0.32 \mathrm{bA}$ & $19.46 \pm 0.38 \mathrm{aB}$ \\
\hline & Day 14 & $12.22 \pm 0.53 \mathrm{cA}$ & $17.39 \pm 0.57 \mathrm{bA}$ & $17.38 \pm 1.20 \mathrm{bAB}$ & $21.68 \pm 0.78 \mathrm{aA}$ \\
\hline & Day 21 & $12.45 \pm 0.99 \mathrm{bA}$ & $16.39 \pm 0.95 \mathrm{aAB}$ & $17.80 \pm 1.58 \mathrm{aAB}$ & $19.79 \pm 0.55 \mathrm{aB}$ \\
\hline & Day 28 & $12.08 \pm 0.39 \mathrm{dA}$ & $16.01 \pm 0.52 \mathrm{cBC}$ & $17.61 \pm 0.63 \mathrm{bAB}$ & $18.06 \pm 0.98 \mathrm{aC}$ \\
\hline & Day 35 & $12.24 \pm 0.32 \mathrm{cA}$ & $16.08 \pm 0.36 \mathrm{bBC}$ & $16.88 \pm 0.39 \mathrm{bB}$ & $17.85 \pm 0.30 \mathrm{aC}$ \\
\hline \multirow{6}{*}{$\mathrm{C}^{*}$} & Day 0 & $20.03 \pm 0.61 \mathrm{cA}$ & $21.69 \pm 0.40 \mathrm{bA}$ & $23.14 \pm 0.29 \mathrm{aA}$ & $22.65 \pm 0.64 \mathrm{aAB}$ \\
\hline & Day 7 & $18.21 \pm 0.52 \mathrm{cBC}$ & $20.68 \pm 0.79 \mathrm{bAB}$ & $21.73 \pm 0.23 \mathrm{bAB}$ & $24.10 \pm 0.91 \mathrm{aA}$ \\
\hline & Day 14 & $18.12 \pm 1.57 \mathrm{bBC}$ & $20.99 \pm 0.74 \mathrm{aAB}$ & $19.15 \pm 0.94 \mathrm{bC}$ & $21.89 \pm 0.34 \mathrm{aBC}$ \\
\hline & Day 21 & $17.16 \pm 0.73 \mathrm{cC}$ & $19.78 \pm 1.04 \mathrm{abB}$ & $20.54 \pm 1.58 \mathrm{abBC}$ & $20.69 \pm 1.12 \mathrm{aC}$ \\
\hline & Day 28 & $18.74 \pm 0.69 \mathrm{bABC}$ & $20.68 \pm 1.09 \mathrm{aAB}$ & $20.38 \pm 0.71 \mathrm{aBC}$ & $21.47 \pm 0.49 \mathrm{aBC}$ \\
\hline & Day 35 & $19.73 \pm 0.46 \mathrm{cAB}$ & $20.70 \pm 0.35 \mathrm{bAB}$ & $19.01 \pm 0.47 \mathrm{cC}$ & $21.72 \pm 0.65 \mathrm{aBC}$ \\
\hline \multirow{6}{*}{$\mathrm{h}^{*}$} & Day 0 & $34.74 \pm 1.01 \mathrm{dC}$ & $43.38 \pm 1.30 \mathrm{cE}$ & $49.96 \pm 1.36 \mathrm{bD}$ & $59.52 \pm 0.64 \mathrm{aE}$ \\
\hline & Day 7 & $40.36 \pm 1.37 \mathrm{~dB}$ & $53.24 \pm 1.25 \mathrm{cC}$ & $60.00 \pm 1.17 \mathrm{bAB}$ & $64.18 \pm 1.28 \mathrm{aBC}$ \\
\hline & Day 14 & $45.38 \pm 1.56 \mathrm{dA}$ & $55.98 \pm 0.96 \mathrm{cB}$ & $62.76 \pm 0.71 \mathrm{bA}$ & $65.24 \pm 1.78 \mathrm{aAB}$ \\
\hline & Day 21 & $43.36 \pm 1.06 \mathrm{cA}$ & $56.02 \pm 1.04 \mathrm{bB}$ & $60.12 \pm 1.18 \mathrm{aAB}$ & $60.80 \pm 0.91 \mathrm{aDE}$ \\
\hline & Day 28 & $35.70 \pm 1.21 \mathrm{cC}$ & $58.68 \pm 1.04 \mathrm{bA}$ & $59.80 \pm 0.99 \mathrm{bB}$ & $67.24 \pm 0.89 \mathrm{aA}$ \\
\hline & Day 35 & $38.28 \pm 0.95 \mathrm{~dB}$ & $50.96 \pm 0.69 \mathrm{cD}$ & $55.42 \pm 1.88 \mathrm{bC}$ & $62.66 \pm 0.43 \mathrm{aCD}$ \\
\hline
\end{tabular}

${ }^{a}$ Averages in the same row with the same superscript letters do not differ significantly by Tukey's test $(p<0.05)$. ${ }^{A}$ Averages in the same column with the same superscript letters do not differ significantly by Tukey's test $(p<0.05)$. Means \pm SD of quintuplicate analyses. $\mathrm{SP}=$ sun mushroom powder. 
The $a^{*}$ value is the most sensitive parameter in the characterization of red color and in the identification of the oxidative stability of meat products (Ramos; Gomide, 2007). As for the color of the sausage in the present study, there was a decrease $(\mathrm{p}<0.05)$ in the $a^{*}$ parameter during storage, i.e. the intensity of red coloring decreased during this period, regardless of the evaluated treatment (Table 4). This reduction of $a^{*}$ values in all the treatments was possibly related to the development of lipid oxidation (Shan et al., 2009).

It is also noteworthy that over the period of storage of the pork sausages, the control treatment had a greater $a^{*}$ value $(\mathrm{p}<0.05)$ than the other treatments with added sun mushroom powder (Table 4), demonstrating a greater intensity of red coloring compared to the other treatments, which was due to the yellowish pigmentation which is characteristic of the incorporated mushroom.

On the other hand, the $b^{*}$ value (yellowness) was unchanged $(p>0.05)$ in the treatment without added sun mushroom powder $(0 \%$ SP). There were small oscillations in the other treatments with added sun mushroom powder $(1 \%, 2 \%$ and $4 \% \mathrm{SP})$ over the period of storage.

However, the control had lower $b^{*}$ values $(\mathrm{p}<0.05)$ compared to the other treatments, which showed an increase in these values that was dependent on the increased level of concentration of added sun mushroom powder (Table 4). This behavior of the yellowness can be understood as being related to the likelihood that the sun mushroom powder was able to change the color of the studied meat products, due to their yellowish pigmentation (Kim, Cho and Han, 2013).

The hue angle $\left(h^{*}\right)$ is the quantity associated with the wavelengths of the visible spectrum; it represents the quality of colors and allows them to be differentiated (Ramos; Gomide, 2007). The chroma $\left(C^{*}\right)$ value expresses the intensity, i.e. the saturation in terms of these pigments $\left(a^{*}\right.$ and $\left.b^{*}\right)$. Chroma values near zero represent neutral colors (grays), while values close to 60 express vivid colors (Mendonça et al., 2003).

It was noted that the $h^{*}$ value of the control treatment was lower $(p<0.05)$ than other treatments with added sun mushroom powder, with the biggest difference shown in the treatment with $4 \%$ added SP during the storage period; this was due to the higher concentration of sun mushroom, which interferes with the quality of the color. In general, the treatments had $C^{*}$ values between 17.16 to 24.10 throughout the storage period.
Venturini et al. (2011) evaluated the color uncured fresh chicken sausage with reduced fat content and obtained $C^{*}$ values (11.75 to 18.98 ) lower than those found in this study. Similarly, the $C^{*}$ values presented for pig shank around 9.0 (Melo et al., 2014).

The microbiological stability of the different treatments of pork sausage, during the storage period of 35 days at $4{ }^{\circ} \mathrm{C}$, was based on counts of aerobic mesophilic and psychrotrophic microorganisms (Table 5), which can be used to indicate the health quality and the safety of meat products; this provides an estimate of the overall population of microorganisms present over a wide temperature range.

According to the results, the microbial population of aerobic mesophilic in the pork sausages showed no difference $(p>0.05)$ with the addition of sun mushroom powder in relation to the values obtained on days 0,7 and 21 of storage (Table 5). Considering these values until the 21 st day of storage, all the treatments showed counts of aerobic mesophilic microorganisms lower than $6.0 \log \mathrm{CFU} / \mathrm{g}$ and remained within the acceptable limit of microbial contamination (Terra, 1998). However, from the 28th day of storage the product visibly changed, with the development of external molds and yeasts.

Fresh sausages are greatly exposed to contamination and represent an excellent medium for the multiplication of microorganisms (Milani et al., 2003), which results in reduced shelf life (Paula et al., 2011). These results corroborate those found in the present study, where the pork sausages were within the acceptable limit of microbial contamination during 21 days of storage and showing that the addition of sun mushroom powder was not able to develop efficient antimicrobial activity.

Similarly, it was not possible to observe lower values ( $p>0.05$ ) for the count of psychrotrophic microorganisms (Table 5) in the treatments with added sun mushroom powder compared to control. Until the 21st day of storage, the counts for this microorganism remained less than $6.0 \log \mathrm{CFU} / \mathrm{g}$, which was within the acceptable limit of bacterial contamination (Terra, 1998).

Considering the microbiological standards established by Brazilian legislation regarding pork sausage (Brasil, 2001), the mean values of the count for Staphylococcus coagulase positive, total coliforms at $35{ }^{\circ} \mathrm{C}$, coliforms at $45{ }^{\circ} \mathrm{C}$ coliforms, Salmonella spp. and sulphite-reducing Clostridium in the samples studied in the early period of storage at $4{ }^{\circ} \mathrm{C}$ met these standards. 
Table 5: Count of total psychrotrophic aerobic mesophilic microorganisms in samples of fresh pork sausage with different added concentrations of sun mushroom (Agaricus blazei Murrill) powder stored at $4{ }^{\circ} \mathrm{C}$ for 35 days in $\log$ $\mathrm{CFU} / \mathrm{g}$.

\begin{tabular}{cccccc}
\hline & & $0 \% \mathrm{SP}$ & $1.0 \% \mathrm{SP}$ & $2.0 \% \mathrm{SP}$ & $4.0 \% \mathrm{SP}$ \\
\hline \multirow{5}{*}{ Total } & Day 0 & $3.88 \pm 0.03 \mathrm{aB}$ & $3.93 \pm 0.09 \mathrm{aB}$ & $4.11 \pm 0.10 \mathrm{aB}$ & $3.97 \pm 0.12 \mathrm{aC}$ \\
mesophilic & Day 7 & $4.06 \pm 0.13 \mathrm{aB}$ & $4.02 \pm 0.05 \mathrm{aB}$ & $4.34 \pm 0.82 \mathrm{aB}$ & $4.23 \pm 0.26 \mathrm{aC}$ \\
aerobics & $4.03 \pm 0.08 \mathrm{cB}$ & $4.09 \pm 0.12 \mathrm{bcB}$ & $4.28 \pm 0.12 \mathrm{bB}$ & $5.12 \pm 0.09 \mathrm{aB}$ \\
& Day 21 & $4.61 \pm 0.22 \mathrm{cA}$ & $4.64 \pm 0.09 \mathrm{cA}$ & $5.36 \pm 0.15 \mathrm{bA}$ & $5.67 \pm 0.28 \mathrm{aA}$ \\
& Day 28 & n.d & n.d & n.d & n.d \\
& Day 35 & n.d & n.d & n.d & n.d \\
\hline \multirow{5}{*}{ Psychotrophic } & Day 0 & $3.74 \pm 0.06 \mathrm{abB}$ & $3.17 \pm 0.18 \mathrm{cB}$ & $4.25 \pm 0.15 \mathrm{aB}$ & $3.65 \pm 0.07 \mathrm{bcC}$ \\
& Day 7 & $3.98 \pm 0.01 \mathrm{aB}$ & $3.86 \pm 0.04 \mathrm{aAB}$ & $4.34 \pm 0.06 \mathrm{aAB}$ & $3.72 \pm 0.05 \mathrm{aC}$ \\
& Day 14 & $3.57 \pm 0.08 \mathrm{bB}$ & $3.12 \pm 0.01 \mathrm{cB}$ & $3.84 \pm 0.09 \mathrm{bB}$ & $5.03 \pm 0.07 \mathrm{aB}$ \\
& Day 21 & $5.04 \pm 0.23 \mathrm{aA}$ & $4.73 \pm 0.15 \mathrm{aA}$ & $5.17 \pm 0.21 \mathrm{aA}$ & $5.99 \pm 0.22 \mathrm{aA}$ \\
& Day 28 & n.d & n.d & n.d & n.d \\
& Day 35 & n.d & n.d & n.d & n.d \\
\hline
\end{tabular}

${ }^{a}$ Averages in the same row with the same superscript letters do not differ significantly by Tukey's test $(p<0.05) .{ }^{\mathrm{A}}$ Averages in the same column with the same superscript letters do not differ significantly by Tukey's test $(\mathrm{p}<0.05)$. Means \pm standard deviation of quadruplicate analyses. $\mathrm{SP}=$ sun mushroom powder. n.d= not detectable; visible external molds and yeasts.

\section{CONCLUSIONS}

Sun mushroom (Agaricus blazei Murrill) powder was shown to be effective regarding the oxidative stability of pork sausage when added at concentrations of $1.0 \%, 2.0 \%$ and $4.0 \%$. It extended the shelf life of the meat products under conditions of oxygen permeable packaging and refrigeration $\left(4{ }^{\circ} \mathrm{C}\right)$. However, there was no a clear effect on the microbiological stability of the meat products. Thus, it was concluded that it is feasible to add sun mushroom powder to pork sausage as a natural antioxidant that is capable of maintaining quality attributes throughout the product's shelf life.

\section{REFERENCES}

AGAHAR-MURUKAR, D.; SUBBULAKSHMI, G. Nutritional value of edible wild mushrooms collected from the Khasi hills of Meghalaya. Food Chemistry. 89(4):599-603, 2005.

AHMAD, S.; SRIVASTAVA, P. K. Quality and shelf life evaluation of fermented sausages of buffalo meat with different levels of heart and fat. Meat Science. 75(4):603-609, 2007.

\section{ASSOCIATION OF OFFICIAL ANALYTICAL} CHEMISTS - AOAC. Official methods of analysis of the Association Analytical Chemists.18. ed. Gaithersburg, Maryland: AOAC. 2005. $1230 \mathrm{p}$.

AMERICAN PUBLIC HEALTH ASSOCIATION - APHA. Committee on microbiological methods for foods. Compendium of methods for the microbiological examination of foods. 4. ed. Washington: APHA, 2001. 676 p.

BISWAS, A. K.; CHATLI, M. K.; SAHOO, J. Antioxidant potential of curry (Murrayakoenigii L.) and mint (Menthaspicata) leaf extracts and their effect on colour and oxidative stability of raw ground pork meat during refrigeration storage. Food Chemistry. 133(2):467-472, 2012.

BRASIL. Agência Nacional de Vigilância Sanitária. Resolução RDC n 12 , de 02 de janeiro de 2001. Aprova o Regulamento Técnico sobre padrões microbiológicos para alimentos. Diário Oficial da União, Brasília, 02, janeiro, 2001, Seção 1, p. 46-53. 
Instrução Normativa $n^{\circ} 4$, de 31 de março

de 2000. Secretaria de Defesa Agropecuária do Ministério da Agricultura e do Abastecimento. Aprova os Regulamentos Técnicos de Identidade e Qualidade de Carne Mecanicamente Separada, de Mortadela, de Linguiça e de Salsicha. Diário Oficial da União, Brasília, 31, março, 2000, Seção 3, p. 7-12.

Instrução Normativa $n^{\circ} 62$, de 26 de agosto de 2003. Secretaria de Defesa Agropecuária do Ministério da Agricultura, Pecuária e Abastecimento. Métodos analíticos oficiais para análises microbiológicas para controle de produtos de origem animal e água. Diário Oficial da União, Brasília, 26, agosto, 2003, Seção 1, p. 1-76.

CAPITANI, C. D. et al. Evaluation of natural and synthetic compounds according to their antioxidant activity using a multivariate approach. European Journal of Lipid Science and Technology. 111(11):1090-1099, 2009.

COMISSION INTERNATIONALE DE I'ECLAIRAGE. CIE publication No 15.2. CIE Colorimetry. 2nd Ed. Paris: Central Bureau of the CIE, 1986, 72p.

DEJONG, S.; LANARI, M. C. Extracts of olive polyphenols improve lipid stability in cooked beef and pork: Contribution of individual phenolics to the antioxidant activity of the extract. Food Chemistry. 116(4):892-897, 2009.

FELLENBERG, M. A.; SPEISKY, H. Antioxidants: Their effects on broiler oxidative stress and its meat oxidative stability. Poultry Science Journal. 62(1):53-69, 2006.

GEORGANTELIS, D. et al. Effect of rosemary extract, chitosan and $\alpha$-tocopherol on lipid oxidation and colour stability during frozen storage of beef burgers. Meat Science. 75(2):266-274, 2007.

GÖK, V.; AKKAYA, L.; OBUZ, E. Effects of packaging method and storage time on the chemical, microbiological, and sensory properties of Turkish pastirma-a dry cured beef product. Meat Science. 80(2):335-344, 2008.

INSTITUTO ADOLFO LUTZ - IAL. Métodos FísicoQuímicos para Análise de Alimentos. 4. ed.; 1.ed digital, São Paulo: Secretaria de Estado da Saúde, cap. 6, p.279-320, 2008.
JOSEPH, S. et al. Oxidative stability of pork emulsion containing tomato products and pink guava pulp during refrigerated aerobic storage. Journal Food Science Technology, Mysore, DOI 10.1007/s13197-012-0820-y. Sept. 2012.

KIM, S. J.; CHO, A. R.; HAN, J. Antioxidant and antimicrobial activities of leafy green vegetable extracts and their applications to meat product preservation.

Food Control. 29(1):112-120, 2013.

MELO, D. S. et al. Meat quality of swine with the use of glycerin in feeding. Arquivo Brasileiro de Medicina Veterinária e Zootecnia. 66(2):583-592, 2014.

MENDONÇA, K. et al. Concentração de etileno e tempo de exposição para desverdecimento de limão 'siciliano'. Brazilian Journal of Food Technology. 6(2):179-183, 2003.

MILANI, L. I. G. et al. Bioproteção de linguiça de frango. Ciência e Tecnologia de Alimentos. 23(2):161166, 2003.

OLIVEIRA, J. M.; ARAÚJO, W. M. C.; BORGO, L. A. Quantificação de nitrato e nitrito em linguiças do tipo frescal. Ciência e Tecnologia de Alimentos. 25(4):736742, 2005.

PAULA, R. et al. Assessment of different packaging structures in the stability of frozen fresh brazilian toscana sausage. Food Bioprocess Technology. 4(3):481-485, 2011.

RAHARJO, S.; SOFOS, J. N.; SCHMIDT, G. R. Improved speed, specifity, and limit of determination of an aqueous acid extraction thiobarbituric acid - C18 method for measuring lipid peroxidation in beef. Journal of Agricultural and Food Chemistry. 40(11):2182-2185, 1992.

RAMOS, E. M.; GOMIDE, L. A. M. Avaliação da qualidade de carnes: fundamentos e metodologia. Viçosa: UFV, 2007. 599 p.

SAGGIORATO, A. G. et al. Antifungal activity of basil essential oil (Ocimum basilicum L.): evaluation in vitro and on an Italian-type sausage surface. Food and Bioprocess Technology. 5(1):378-384, 2012.

Ciênc. Agrotec., Lavras, v. 39, n. 4, p. 381-389, jul./ago., 2015 
SHAN, B. et al. Antibacterial and antioxidant effects of five spice and herb extracts as natural preservatives of raw pork. Journal of the Science of Food and Agriculture. 89(11):1879-1885, 2009.

SOARES, A. A. et al. Antioxidant activity and total phenolic content of Agaricus brasiliensis (Agaricus blazei Murril) in two stages of maturity. Food Chemistry. 112(4):775-781, 2009.

TAVEIRA, V. C.; NOVAES, M. R. C. G. Consumo de cogumelos na nutrição humana: uma revisão da literatura. Comunicação em Ciências da Saúde. 18(4):315-322, 2007.
TERRA, N. N. Apontamentos de tecnologia de carnes. São Leopoldo: Unisinos, 1998, 226p.

TERRA, N. N.; BRUM, M. A. R. Carne e seus derivados - técnicas de controle de qualidade. São Paulo: Nobel, 1988. 121p.

TOMIZAWA, M. M. et al. Variabilidade genética de isolados do cogumelo Agaricus blazei por meio de marcadores RAPD. Ciência e Agrotecnologia. 31(4):1242-1249, 2007.

VENTURINI, A. C. et al. Sensory and microbiological evaluation of uncured fresh chicken sausage with reduced fat content. Food Science and Technology. 31(3):629-634, 2011. 